History of the Human Sciences

2016, Vol. 29(1) 117-122

The Natural Law Foundations of Modern Social Theory: A Quest for Universalism

\title{
Jordi Mundó
}

University of Barcelona, Spain

In recent years a body of academic literature has appeared that seeks to address the problem of cosmopolitanism in an economically globalized capitalist world that is characterized by enormous social and cultural diversity. The Roman law concept of ius gentium institutionalized the acknowledgement of the unity of humanity in its diversity. However, the path from the solution that Roman law proposed for this problem (with its roots in Stoicism) to today's universal declaration of human rights has gone through many different stages over the centuries, and has been addressed from opposing philosophical perspectives.

\section{Corresponding author:}

Jordi Mundó, Faculty of Economics, University of Barcelona, Av. Diagonal 690, 08034 - Barcelona, Spain.

Email: jordimundo@ub.edu 
In the social sciences the difficulty created by this plurality of approaches to the question of human universality is compounded by three other fundamental problems as well. The first is the evidence that the core of research in modern social theory has been systematically disconnected from the problem of normativity. The second is the increasingly ahistorical nature of the methodology of social analysis; and the third is the fact that the sphere of social reflection has expanded into a field of fundamentally empirical analysis that is disconnected from other adjacent, non-social disciplines. This consolidation of sociology as an independent discipline has led to a de facto separation of the description of complex social realities from the reflection upon what would be normatively desirable for the common good.

Bearing these points in mind, the skilful exercise in philosophical sociology that Daniel Chernilo develops in his recent book examines the question of how universalism might be considered in social theory today, in order to analyse and resolve problems of human beings in society without recourse to transcendental propositions. After expanding on certain ideas already sketched in his previous book (Chernilo, 2011) the author proposes a post-transcendentalist programme for the renormativization of social theory. His programme foregrounds the deontological aspects which are inherent to human sociality and are essential to solving the problems that contemporary social science should address. To this end he puts together a powerful argument based on the notion of universalism. In his exploration of the different problems associated with universalism 
he revives a vigorous universalistic tradition which has been progressively eclipsed by the development of contemporary social science: the natural law tradition.

Chernilo convincingly shows how modern social theory has sublated the natural law tradition, and he does so without over simplifying or assuming that social science is merely a continuation of it:

Modern social theory is not the most recent incarnation of natural law. The language and modes of addressing social life have altered fundamentally, of course, and yet the social sciences can be seen as one particularly modern form of posing questions that are not altogether different from those the natural law tradition has long been raising. (3)

There are two reasons why social science is not a mere continuation of the natural law tradition. First, a significant part of the social theory which emerged in the 19th century and became consolidated in the 20th had a primarily empirical basis (at times, a radically positivist one) and had little to do with the principles of natural law. Second, there is a discontinuity between social theory and the influential branch of natural law based on precepts of metaphysical and transcendental origin and substantive ends. However, despite these major conceptual and theoretical obstacles, Chernilo is able to pinpoint significant relationships between the natural law tradition and any substantial proposal of a social theory that recognizes a common ontological domain of human sociality. Even acknowledging that the question of what modern social theory has 
inherited from natural law has at best been avoided by key thinkers in the development of twentieth-century social theory (Aron, Giddens, Hawthorn, Seidman), or at worst been treated with contempt (Foucault, Lyotard, Rorty, Luhmann, Latour), Chernilo's book ably identifies the presence of natural law in different traditions within the philosophical and sociological literature: Christian natural law (Messner), mainstream sociology (Selznick), Marxism and critical theory (Habermas, Fine, Wellmer), political theory (Strauss), classical Greek philosophy (Gouldner, Inglis and Robertson, McCarthy), modern science (Toulmin), the history of political and social concepts (Koselleck), and the Cambridge School (Skinner, Tuck).

In developing these connections the author draws attention to the importance of the inherited versions of natural law in the writings of Hobbes, Rousseau, Kant and Hegel, and elegantly dissects those contributions of classical social theorists such as Marx, Tönnies, Durkheim and Weber that have their roots in natural law. The recurring argument he puts forward is that whereas natural law emerged with an explicit set of ideas about human nature (ideas which also had a substantive quality) social theory has for the most part operated with implicit notions of human nature but with explicit notions of the social. Chernilo posits that universalism may constitute the link that allows social analysis to recover its necessary normative dimension. This idea is beautifully expressed in his perceptive analysis of the current state of social theory: 
For all its theoretical sophistication and its several attempts at the constitution of general theories of society, our understanding of the philosophical foundation of modern social theory remains relatively unsatisfactory; for all its methodological sharpness, creativity and originality, claim on radical innovation, complete rupture and thoroughgoing novelty are in fact part of a long-standing heritage, repeat themselves far too often and are still being accepted far too readily; for all its sensibility towards sociohistorical particularity and empirical detail, our reconstructions of the sociological tradition remain surprisingly self-centered on what social theorists say to themselves; for all its passions for political action, we still struggle to come to terms with social theory's normative implications and the challenge to locate the normative in society. (223-4)

The implication here is that the more social scientists explore the foundations of human life and behaviour, the more pressing the questions about the human condition become. Chernilo holds that universalism takes the relationship between people's individual motivations and their sense of obligation very seriously. He is fully aware that universalism is normative in nature, and that it is not necessarily fostered by social life; rather, the statements we make about our common existence, what we refer to as human life, depend on our ability to construct a sense of universal belonging.

However, this theoretical approach raises a question of great importance: is it possible to re-establish the universalistic aspirations of social theory while avoiding metaphysical and teleological formulations but at the same time proposing something that goes beyond a vague, ambiguous, purely formal and ecumenical definition of universalism? My own view is that although Chernilo's overall approach is a valid one, 
implicit within it there are two serious problems that will need to be addressed in any future reflections on the matter. The first is the need to acknowledge that natural law is not a singular tradition but a plural one, and that some of its currents are incompatible with one another. The other is the fact that some camps within modern social theory are opposed to any form of reflection on natural law - a situation which in fact supports Chernilo's call for the development of a genuine normative programme of philosophical sociology.

In order to address the first of these problems we need to start from a sufficiently broad definition of what we mean by the 'tradition' of natural law, and then determine its central focus. In addition to its roots in the Stoic and Roman worlds, and in order to understand its role in the American and French revolutions (Gauthier, 2014), we should bear in mind that many of the formulations put forward by authors in the 17th and 18th centuries had their origins in complex medieval and late medieval re-workings of what would come to be 'modern' social and political problems: the individual, freedom, domination, property, sovereignty, and rights. Although Chernilo's attempt to propose a profound recategorization of the history of intellectual traditions through his notion of early Enlightenment is extremely thought-provoking, the course he traces through history is not entirely convincing, as Tierney (1997) very skilfully shows. If we ignore the reformulations of authors such as Peter John Olivi and Henry de Guent, Michel Villey and William of Ockham, or Jean Gerson and Francisco Suárez, it is difficult to 
grasp fully the backdrop to the work of the natural law scholars of the seventeenth and eighteenth centuries. For example, we might not see that Filmer's theory of natural subjection is radically opposed to the theory of natural liberty that one finds in Locke, Overton or Sydney, and we might remain unaware of the consequences that these different approaches had for the different branches of natural law - consequences which continued to cast their shadow until the nineteenth century. This is because, for example, an interpretation of purely formal natural law is not the same as an interpretation of substantive natural law, since the latter would link up with the 'socialist' tradition of rights (Swedberg, 1998: 96-7). Aspects as fundamental to the problem of universalism as the right of citizens to revolt against the absolute power of the monarch, their religious freedom and the critique of colonization converge around an issue that is central to any modern universalistic proposal: the problem of inalienability. The inalienability of mastery over oneself and the political, moral and economic rights that follow from this is a recurrent problem in the work of Machiavelli, Harrington, Locke, Adam Smith, Kant and Marx. Chernilo does invoke the concept of inalienability when he refers to "a view about what the inalienable features of our common humanity are" (4), or to the promotion of "a sense of equality and justice in which human beings are to treat one another as bearers on an inalienable dignity that is to be upheld irrespective of their particular affiliations" (5). In my view, however, a more detailed account of the historical, philosophical and political background to the 
problem of inalienability would enable us to trace the formation of the modern world more precisely and to see that we can only really understand modernity if we acknowledge that the universalist tradition is largely founded on the institutionalization of inalienability.

The second problem has to do with the ontological domain of social theory and its potential relationship to universalism. From the descriptive perspective, says Chernilo, modern social theory requires a universalistic perspective in order to explain the social as an autonomous and emergent ontological domain. And from the normative perspective, he argues that social science must remain committed to universalism, seek to refine its proposals, and explore its reflexivity in greater depth, since its task is to return to promoting forms of life that are more inclusive, open and fair. As Chernilo rightly says:

Modern social theory is the natural law of an emergent and artificial realm - social relations - because: (1) it works under the presupposition that social relations do have a nature; (2) seeks to understand what is unique or 'artificial' in that nature; and (3) locates the normative in social relations as a strictly immanent realm whose transcendental limit lies in our universally shared humanity. (220)

In my view, however, this falls short of an adequate definition of what we understand by 'social theory'. Clearly, many of the problems facing contemporary social theory are caused by the hegemony of neoclassical economic theory, which, despite being a 'social 
theory', has constantly defined itself as a science that is dissociated from any sociological, legal, political or anthropological theorization. This separation is not merely a methodological problem, but has serious consequences for any universalistic programme. The split that occurred in 19th-century social science (recall the utilitarian Bentham's comment that the term 'natural rights' was 'simple nonsense: natural and imprescriptible rights, rhetorical nonsense - nonsense upon stilts'), and particularly after the marginalist revolution, contributed decisively to the institutionalization of sociology as an independent discipline. Economic theory was built upon the assumption of a reductionist rational behaviour - that is, self-interest - that allowed rational agents to maximise their utility. This premise enabled it to conduct a-historical and ainstitutional analyses of human behaviour and action (as the economist Abba Lerner put it so starkly but accurately (1972: 259): 'Economics has gained the title of queen of the social sciences by choosing solved political problems as its domain'). By contrast, sociological theory limited its field of analysis to problems that neoclassical economic theory had abandoned (in spite of their prominence in the older tradition of political economics), namely social change, conflict, inequality, trust, social class and the very notion of sociality itself (Hodgson, 2001). With these reflections in mind, one can see more clearly that Chernilo's overall approach is well-founded, since his connection or "re-connection" of the foundations of the best normative social tradition with the old tradition of natural law obliges us to recognize the complexity and variability of human 
motivations and actual behaviour. For the author, social theory's debt to natural law is apparent in its presupposition of the universal dignity of human beings as competent agents in the social world. It is human beings who create and recreate society even as this takes place in prestructured settings that are not the result of current actors' making. His view here is based on the idea that, ultimately, the universalist leanings of social theory have to do with the notion of humanity as an increasingly socio-cultural entity:

Social theory does not explicitly spell out its universalistic presuppositions about our shared humanity because that would effectively undermine its own intellectual case - the theoretical account and empirical description of social life. The problematic centrality of universalism lies here in that social theory requires the presupposition of the unity of human species ultimately without, however, being able to found that argument". (208)

So Chernilo holds that modern social theory must renew itself, primarily by capturing the forms that universal human affairs take on in the modern world. This requires combining long-standing ways of thinking with the more empirical means of modern science.

These two problems constitute serious challenges. Despite the anti-foundationalist, antihistorical and resolutely constructivist turn taken by some lines of sociological research, social theory's recognition (implicit or explicit, but nonetheless constitutive) of nonreductionist - multi-motivational - rational assumptions regarding human action link it 
potentially to the core of the problem of universalism. In this regard, sociological theory with a historical focus would appear better suited to integrating a universalistic programme than neoclassical economic theory. Accepting that human nature comprises a plurality of motivations allows us to explore the complexity of the problem of universalism in a context of social and cultural diversity by providing empirical evidence and by putting forward normative proposals that are beneficial to humanity as a whole. These assumptions serve to formulate a notion of non-transcendentalist universalism like the one described by Chernilo, and it is a notion that underlies some of the constitutive elements of the modern world: republican democracy, enlightened freedom and universal human rights. In a world riven by social inequalities, and in which the question of the inalienability of political and economic rights is under serious threat, Chernilo's proposal is a deeply serious and ambitious attempt to strengthen the role of social theory as a fundamental discipline for science and society in the $21 \mathrm{st}$ century.

The importance of the universalistic dimension of social science becomes apparent when one considers that the notion of human rights disappeared from European constitutional doctrine (and, of course, from the philosophy of law) for 150 years: there is not a single reference to human rights in any constitutional text between 1794 (after Thermidor) and 1945 (after the defeat of Nazism). If social science is to reach an adequate understanding of this universalistic dimension, and if it is to recover the 
normative tradition it has lost, it needs to break out of its comfort zone and (re)engage with the historical and philosophical reflections of natural law - a move that would constitute a genuine exercise in philosophical sociology. As Tönnies (2005: 57) said in his speech to the 1910 conference of the German Society for Sociology, putting forward an argument that Chernilo expands upon so well in his book:

Sociology is first a philosophical discipline. As such, it is much older than its name. The name did not create it, nor did the person who coined the name bring it into being. Speculation about the essence of human society, especially political alliances, has always been closely connected with the ideas of ethical and good conduct of life and forms of life. [...] The development of theoretical sociology, which may also be called "social philosophy", is, then, inseparable from the history of legal philosophy.

\section{References}

Bentham, J. (1843) The Works of Jeremy Bentham. Ed. J. Bowring, Edinburgh: William Tait, vol. II.

Chernilo, D. (2011) La pretensión universalista de la teoría social [The Universalist Claim of Social Theory]. Santiago de Chile: LOM ediciones.

Gauthier, F. (2014) Triomphe et mort de la révolution des droits de l'homme et du citoyen (1789-1795-1802) [Triumph and Death of the Revolution of the Rights of Man and of the Citizen (1789-1795-1802)]. Paris: Éditions Syllepse. 
Hodgson, G. M. (2001) How Economics Forgot History. The Problem of Historical Specificity in Social Science. London and New York: Routledge.

Lerner, A. (1972) 'The economics and politics of consumer sovereignty', American Economics Review 62(2): 258-266.

Swedberg, R. (1998) Max Weber and the Idea of Economic Sociology. Princeton, NJ: Princeton University Press.

Tierney, B. (1997) The Idea of Natural Rights. Studies on Natural Rights, Natural Law, and Church Law 1150-1625. Grand Rapids, MI and Cambridge: William B. Eerdmans Publishing Company.

Tönnies, F. (2005) 'Ways and goals of sociology', in C. Adair-Toteff (ed.) Sociological Beginnings: The First Conference of the German Society for Sociology. Liverpool: Liverpool University Press, pp.57-73.

\section{Author biography}

Jordi Mundó is Professor of Moral Philosophy and Philosophy of the Social Sciences at the University of Barcelona. He has authored books on epistemology of the social sciences and published several book chapters and articles on political philosophy, conceptual history, ethics, and social cognition. In his current research he analyses the wide-ranging conceptual recategorization that took place in philosophy and history 
regarding the political and social philosophy of the nineteenth century, and examines its consequences for social science, political philosophy and law in the twentieth century. 